Between 1953 and 1959 the federal contribution to industrial research expenditure increased sharply, and overtook the industrial contribution in 1956 . Since then the scales have begun to tip the other way. American industry in 1965 financed some 45 per cent of the research work which it carried out, while federal support made up the rest.

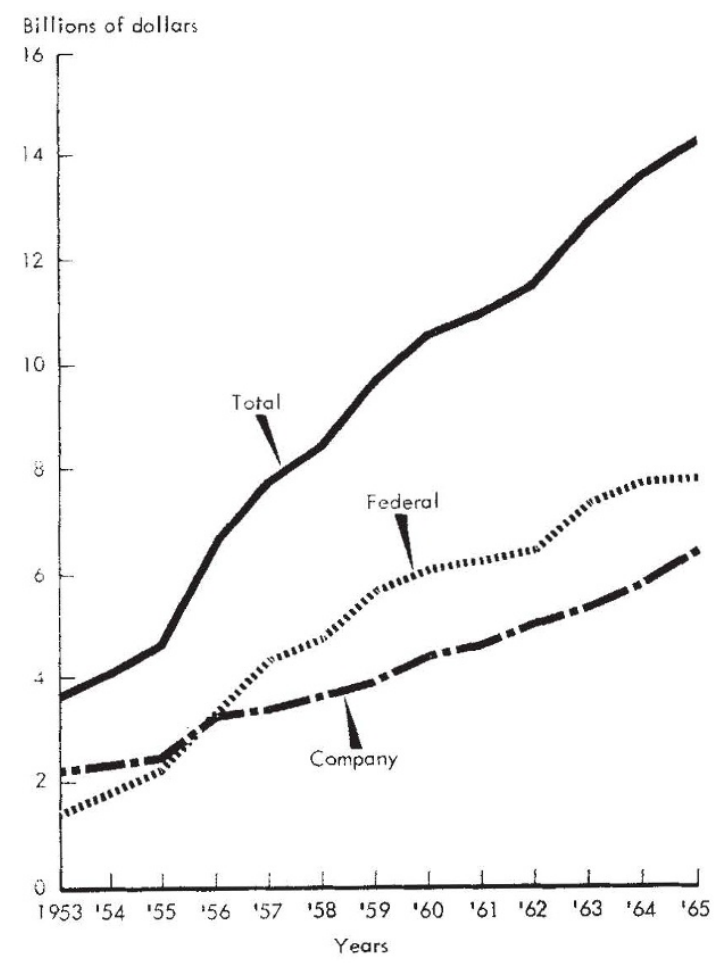

The changes in distribution are naturally over. shadowed by the sheer growth of research expenditure since 1953. Total expenditures have increased since then from $\$ 3,630$ million to $\$ 14,197$ million. Companies in the aircraft and missile business accounted for more than a third of this, some $\$ 5,120$ million, while research in the electrical equipment and com. munication business amounted to $\$ 3,167$ million. Just under 90 per cent of the aircraft and missile research was supported by federal funds, as was more than 60 per cent of the electrical and communication research. At the other end of the spectrum, the chemical and allied products industry found 85 per cent of its research expenditure from its own pocket.

Overwhelmingly the advantage lies with the big battalions. The eight companies with the largest research and development expenditures accounted for 11 per cent of net sales, 13 per cent of total employment, and 47 per cent of all federally supported research. There were some 13,400 companies conducting research in the United States in 1965 , but 87 per cent of the research was done by about 3 per cent of the companies. Among large companies, 29 had research and development programmes costing more than $\$ 100$ million and made up $\$ 9,000$ million of the total expenditure.

More than half the scientists and engineers working in industrial research worked in the aircraft, missile, electrical and communications industries. Together with chemicals and allied products, machinery, motor vehicles and other transport equipment, these industries employed 81 per cent of the qualified manpower. In January 1966, the total number of scientists and engineers employed in research and development was 358,900 .

\section{Monumental Masonry}

IN $1955 \mathrm{Mr}$ Michael Rix invented the name industrial archaeology. Although some say that industrial monuments are too recent to be considered archaeological relics, $\mathrm{Mr}$ Rix points out that an eighteenth century ironworks, the model $T$ Ford and the orystal set are really as out of date as a Stone Age axe. In a pamphlet called Industrial Archaeology, published by the Historical Association (3s. 6d.), Mr Rix makes a convincing case for industrial archaeology and, in particular, for preserving the monuments of the Industrial Revolution before it is too late. This is especially important in Britain, of course, where the Industrial Revolution began and where there are many of its relics.

The pamphlet makes encouraging reading, and the increase in the number of industrial museums, the founding of the journal Industrial Archaeology and the encouragement and indirect support of the Government point to the rapid expansion and interest in industrial archaeology. The most immediate problem is to assess the importance of sites and items. Nobody knows exactly what relics of the Industrial Revolution are still left scattered about the country. A national survey of industrial monuments is being made under the auspices of the Council for British Archaeology, which receives some support from the British Government. This survey is being co-ordinated by Mr Rex Wailes, who, before joining the Council for British Archaeology eighteen months ago, acted as a consultant to the Ministry of Public Building and Works. Mr Wailes collects information and presents proposals for the preservation of industrial monuments to the council. If they are agreed upon, the council makes representations to the Government asking for a preservation order.

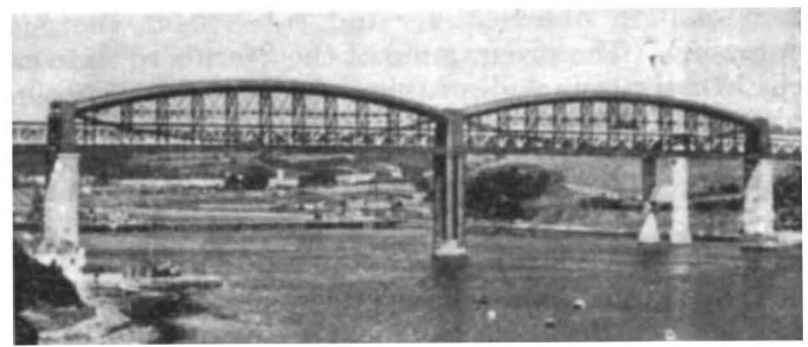

Railway bridge across the Saltash, built by I. K. Brunel for the Great Western Railway. The modern suspension bridge can be seen in the background. (British Rail photograph.)

At the same time, a national record of industrial monuments is being maintained at the Centre for the Study of the History of T'echnology at Bath University of Technology. But progress is slow and depends almost entirely on the work of individuals and local archaeology societies. In a progress report in the 
current issue of Industrial Archaeology, Dr A. Buchanan, the director of the centre, says he has adequate records for only three counties-Hertfordshire, Somerset and Staffordshire.

Many monuments have been preserved. The New Lanark industrial estate, which incorporates the technology of Arkwright with the social planning of Robert Owen, and Coalbrookdale, where Abraham Darby first successfully smelted iron ore with coke, are obvious and famous examples. But these are exceptional and the list of industrial monuments which have been destroyed is depressingly large and growing steadily. As things are, the relics of the transport revolution, canals, turnpike roads and railways, with their magnificent bridges. are more than ever threatened.

\section{Oxford on Iron Rations \\ from our Oxford Correspondent}

THIs week the governing bodies of British universities will be examining the details of their Quinquennial Grants from the University Grants Committee, but few of them, perhaps, with as little delight as Oxford. Yet at first sight, Oxford's grant seems generous. In 1965-66, of Oxford's total income of $£ 8.0$ million, the UGC provided $£ 5 \cdot 25$ million, with a further million pounds of government money coming from research councils and other public bodies. By comparison, the recurrent grants for the next five years are:

\begin{tabular}{|c|c|c|}
\hline 8 & $1968-69$ & $1969-70$ \\
\hline $6.1 \mathrm{~m}$. & $£ 6.2 \mathrm{~m}$ & $£ 6.4 \mathrm{~m}$. \\
\hline
\end{tabular}

Equipment is to be provided for separately from these grants.

In fact, the increase in the grant since 1966 will do little more than cover increases in salaries and prices during the period so that, according to the Hebdomadal Council, there will be no additional funds available for new expenditure next year. At the same time, universities are having to repay sums to the Grants Committee in compensation for the increase in their incomes from the higher fees of overseas students. Oxford, however, refused to increase these fees, so that $£ 63,000$ will have to be paid from the university's own funds, with none of the income for which it would have been a compensation. These payments are expected to increase over the five years.

Even if the Quinquennial Grant had been less parsimonious, the devaluation of the pound would doubtless have forced economies on most university faculties, especially on the science side. Ironically, devaluation will harm those university departments the growth of which the committee had hoped to encourage by increased allocations. The Bodleian Library, for example, has long been short of funds; in 1963-64 its total income was only $\$ 1.75$ million (at the old rate) compared with nearly $\$ 6$ million for Harvard University Library. The Quinquennial Grant contains provisions for increasing library expenditure by 20 per cent per student. How far this will be vitiated by devaluation and the increased cost of some books, it is too early to say. In the same way, the growth of Middle Eastern and Latin American studies will be slowed down and these departments, as well as the science faculties, will be waiting earnestly to hear that the government will compensate for the fall in the value of the pound.
There is therefore little hope that Oxford will be able to expand its activities, even though it receives public money from a variety of sources. Increasing college fees-paid for in the main by local authorities-is no light matter and, even if tuition fees are increased, colleges will be able only to appoint a few new tutors to help out penurious university departments. Even so, the majority of college tutors depend in part on university emoluments, paid for by the UGC. Finally, whatever elasticity of this kind there may be in arts faculties, there is far less in science, where the expense falls almost entirely on the Grants Committee and the various research councils. These latter will shortly be issuing their own estimates; if they are equally disappointing, then Oxford will indeed have to live on rather sparser fare than might have been hoped.

\section{Money for Harvard}

Harvard University is trying to raise nearly $\$ 50$ million for an ambitious (some might say, luxurious) programme to make science more exciting for undergraduates at Harvard College. Of the total sum, $\$ 14.5$ million will be used to build a new science centre, with laboratories, computers and a library, in which undergraduates will be encouraged to do research. Their efforts to do this now are inhibited by the demands of graduate and post-doctoral research. Another $\$ 12.6$ million has been budgeted for a new centre for research and teaching in biochemistry and molecular biology (fields in which Harvard has four Nobel Laureates). A project is also indicated to endow: five professorships, in astronomy, biology, engineering, mathematics and physics.

More than one fourth of the several thousand undergraduates at Harvard take degrees in science. The others, who read humanities or social sciences, must spend at least a small fraction of their time at Harvard studying science or the history of science. They, as well as the science undergraduates, will benefit fron "a programme for science" as it is being called. Harvard says that it is conscious of its responsibility to give all of its students, especially those who will become teachers, some acquaintance with what modern science is about.

\section{Physics Directory}

THE ninth edition of the Directory of Physics and Astronomy Faculties has been published by the American Association of Physics Teachers and the American Institute of Physies for the period 1967-68 (\$3). The purpose of the directory is to list those universities in America, Mexico and Canada which offer physics courses and the members of staff who teach these courses. The information which has been collected is part of the procedure used to improve coverage of the National Register of Scientific and Technical Personnel which is maintained by the American Institute of Physics under the sponsorship of the National Science Foundation.

Also listed this year are departments of astronomy and astrophysics, but this section is incomplete and it is hoped that better coverage will be given next year. The directory is divided into seven parts: part one provides a geographical listing of personnel and institu. 